\title{
The Role of Media and Islamic Criminal Legislation in Reducing Crime (From the perspective of students of the University of Jordan)
}

(1) Dr. Husain M. Rababah, Department of Islamic Studies , University Faculty of Ajloun , Al-Balqa Applied University , Ajloun , Jordan .

E-mail : h_rababah1@bau.edu.jo

(2) Dr. Yousef Al-Shurman, The Head Of Department of Social Sciences, University Faculty of Ajloun, Al-Balqa Applied University, Ajloun, Jordan .

E-mail : dr_y_al_shurman@bau.edu.jo

(3) Dr. Nedal H. Momani, Department of Islamic Studies , University Faculty of Ajloun , Al-Balqa Applied University, Ajloun , Jordan .

E-mail : asamanedal@bau.edu.jo

(4) Dr . Eyad Adnan Alhussan , Department of Social Sciences, University Faculty of Ajloun , AlBalqa Applied University, Ajloun, Jordan .

E-mail : eyadhussan@bau.edu.jo

(5) Prof. Mohammad M AL-Hussainat Balqa Applied University Department Of Social Sciences, Ajloun , Al-Balqa Applied University, Ajloun Collage , Jordan .

E-mail : mohammadhussainat@bau.edu.jo

\begin{abstract}
The study aimed to know the role of the media and its various styles, as well as the role of Islamic criminal legislation in reducing crime and identifying the obstacles that limit the effectiveness of the media in the prevention of crime.

A random sample of 600 students was selected at different university levels at the University of Jordan, as well as personal background factors (independent variables): sex, place of residence, specialty, so that eleven different positions were identified, asking the respondents to determine their opinion on their respective trends.
\end{abstract}

Keywords: Role, Media, Islamic Criminal Legislation, Crime

DOI: $10.7176 / \mathrm{JPCR} / 44-05$

Publication date: September 30th 2019

\section{Introduction :}

The various digital, electronic and traditional media play an effective role in the struggle against crime. It is advisable to use it through the provision of programs, lectures and seminars in which all forms of crime, extremism, terrorism, drugs or anti-social currents, or spreading hatred among members of society, It also demonstrates the strong role of security and penal institutions in prosecuting and punishing criminals and activating the preventive role by Awareness members of society not to engage in criminal behavior by adhering to social, religious and spiritual principles, and strengthening the supervisory role of various institutions such as the family and school. (Al-Abdullah, 2010) 
Crime as a social phenomenon known to humanity from its earliest beginnings, by QABEL the son of our master Adam peace be upon him when he killed his brother HABEL, and crime will remain inherent to human societies in their existence.

Islamic criminal legislation derived from the Holy Quran and the Sunnah Prophet has an important role in reducing the crime through the system of sanctions, which is the Qassas ( punishment) and Hodod and Taizir , which is a great deterrent to prevent the perpetration of crimes, in accordance with the words of God (And there is for you in legal retribution [saving of] life, $\mathrm{O}$ you [people] of understanding, that you may become righteous.)( The Holy Quran, surat Al-Baqra:179)

\section{the importance of studying :}

This study identifies the importance of this phenomenon and its reflections on the society. In theory, it highlights the positive role of the various media in struggle crime in its different forms through its direct impact on the social awareness of the members of society to serve the security and safety of societies in light of the high rates of crime. Islamic criminal legislation in reducing this phenomenon and its negative effects on society.

\section{the study Problem :}

The media revolution of the twentieth century as a result of political, social and economic changes has made the new media (digital media), Plays an active role in spreading his message regardless of the negative and positive aspects of the content of this message and non-compliance with the restrictions of freedom of expression, This study was designed to reveal the role of Islamic media and criminal law in reducing crime.

\section{Study Questions:}

1- What role does media play in crime prevention?

2- What media methods are used to prevent crime?

3- What are the obstacles that limit the effectiveness of different media in preventing crime?

4- What is the role of Islamic criminal legislation in reducing crime?

\section{Objectives of the study:}

1. Identify the role of media in crime prevention.

2. Identify media methods in crime prevention.

3. Identify the obstacles that limit the effectiveness of the media in the prevention of crime.

4. Identify the role of Islamic criminal legislation in reducing crime.

\section{Theoretical framework}

The crime in general constitutes a constant threat to social peace, security and stability in the societies of the world, which necessitates the building of effective strategies to combat this crime in all its forms through organized Arab efforts and cooperation between the Arab and Islamic countries in the exchange of information and experience to implement clear strategies that set clear and studied objectives for all Arab countries under the supervision of The League of Arab States represented in the General Secretariat of the Council of Arab Ministers of Interior with the identification of effective national mechanisms to coordinate and implement these strategies through the exchange of mechanisms, information, methods and experiences at the level of Arab well.

The media defined: that the free and objective transfer of news, information and facts is correct in one of the media means targeting the mind and does not aim for any purpose other than the media itself for the purpose of distinguishing between evidence and propaganda (Turki, 1984: 227).

The media are the emotions that lead to the receiving audience around them through hearing and sight (Mathkoor, 1975, p. 64)while the peace media defined that all the relevant media, advocacy and awareness of the peace of the individual and the community and the peace of the homeland and its gains under the purposes and interests considered (Al-Jahni, 1990: 161).

The crime is defined: as a voluntary act that contravenes the law imposed on it (Taleab, 2002: 24). 
The offense is legally defined as: (Crime considered criminal behavior) is any act or omission of a behavior or an act that is criminalized by the project and provided for by law representing a penal base applied to those who are exteriors from it.(Hrish, 1999: 48).

Social definition of crime: It is a Exit from the standards of society or the rules of consensus of any rules determined by society and control the behavior of its members or those acts that represent a danger to society and make it impossible to achieve co-existence and cooperation between individuals who make up the community or are any violation of the feelings of social loyalty (Ghanem, 1994: 39).

But the crime: it is a voluntary act that contravenes the law imposed on him to follow him (Talb, 2002: 24).

The crime is legally defined as: (the crime is considered a Criminal behavior) is any act or abstention of a behavior or an act that is criminalized by the legislator and provides for a law that represents a penal rule applied to those who are exiled from it (Hrish, 1999: 48).

Social definition of crime: It is a deviation from the standards of society or the rules of consensus of any rules determined by society and control the behavior of its members or those acts that represent a danger to society and make it impossible to achieve coexistence and cooperation between individuals who make up the community or are any violation of the feelings of social loyalty (Ghanem, 1994: 39).

Crime in Islamic Jurisprudence: It is a legal taboo, which Allah has denied by Hodod or Taizir (Al-maroudi, 2002: p119).

The concept of media: The media are closely linked to the political system prevailing in all countries of the world (Nimmo \& Mansfeild, 1982: p82)the studies of media and crime have crystallized in three main theories: learning theory, which is related to social psychology, the theory of emptying and the theory of implantation, which is related to Aristotle's philosophical writings. (Shoman, 1420 Hejri).

The modern technological development in all areas of life made the world a small village where it removed the borders and jumped over the dams and made the news beyond the oceans and see it from the end of the globe at the moment of occurrence and if it is at the opposite end of it, where the power of the media and the speed of the extension and the breadth of coverage Geographic, And has the power to move security issues and guide them by means of serious changes in the direction of public opinion where the media planned him, and Islam has known the psychological impact of the media for a long time, where the media used in the invasions and Islamic battles and shows that in the words of the Prophet Muhammad Peace be upon him " A terrifying victory march month" This shows the security and psychological impact of the media, This has also become clear in the international community in the Cold War, which was its deadly media weapon and the resulting psychological war, rumors and intellectual invasion, and can be observed through: When the Arab media refer to the prohibition of theft, assault on others, drugs, terrorism, unlawful killing, the prohibition of adultery and the eating of people's money, In this way, people know that there is a penalty of iniquity in the Hereafter to commit such acts in addition to the worldly punishment. Here, the media plays the role of deterrence and forbidding committing such offenses, And also when the media disseminates the importance of solidarity and helping others, this contributes to the fight against poverty and strengthen the solidarity of citizens, and Islam is keen to take care to fight false rumors, Therefore, it is prohibited to publish the news of the crime only after ascertaining its credibility, as we can not build our information on the suspicion and that to preserve the sanctity and privacy of others. (Al-Janhi, 2000: pp. 105-107).

\section{Islamic Media and Crime}

Quran is the basis of Islamic media, and the largest media, and its verses are considered the head of media materials (Heshem,2009). The Islamic media have forbidden the Qur'aan and the Sunna to kill the soul, which Allaah has forbidden except by truth, Injustice and eating people's wealth, And adultery and the imposition of punishment for these crimes, and others in this world and the Hereafter; the penalty of adultery, which is the value of Islam, God Almighty said: The woman and the man guilty of adultery or fornication,- flog each of them with a hundred stripes: Let not compassion move you in their case, in a matter prescribed by Allah, if ye believe in Allah and the Last Day: and let a party of the Believers witness their punishment.( The Holy Quran, surat elnoor,2) ; The Hudod (limits) prevent him from doing so, and the guilt and punishment of the afterlife will fall from him. between this aspect of the media to reduce the crime of the Qurtubi in that it is intended to be in the presence of people to preach it, And spread his speech to be considered after him, or pray for them repentance and mercy. (Qurtubi,1964), The punishment was applied in front of all the people and participated in it to reduce the crime of alcohol abuse: "He ordered him to Stoning the prayer" (al-bokari,256 Hejri). 
I informed the Muslim nation of the farewell speech by Islamic criminal legislation to limit the crime. He said: «God Blessed and Exalted have deprived your blood and your money and your symptoms except her right ... but you have accomplish». (al-bokari,6785), And this is an Islamic media in the large councils also aimed at reducing the crime said the Prophet - peace be upon him - in the Council, said: «My promise that you do not share anything with God and do not steal, do not Adultery» (al-bokari,6784 )

And here comes the Islamic media in Surat Al-hujrat to build a moral society takes a dirham to prevent crime, and rumors to reduce crimes, must unite society and cooperation to resolve disputes and reduce crimes, and not to ridicule or stab others and mistrust them because it is the cause of many of the crimes, Non-interference in the privacy of others, and spying on them, to prevent the causes of crimes; because people are equal no difference between male, female in the media and Islamic criminal legislation to reduce crime.

The goal of the Islamic media in peacetime: to spread security among people and to create hearts, to provide the ideal to prevent the occurrence of crimes in societies, and the way to such crimes only through the example of the human approach, so the media are required to provide a good example, Islamic religion Many of these models, God said (Ye have indeed in the Messenger of Allah a beautiful pattern (of conduct) for any one whose hope is in Allah and the Final Day, and who engages much in the Praise of Allah.)( The Holy Quran, surat alahzab,21)To fully enforce the responsibility for advocacy, and the call for tolerance and freedoms.(hesham.2009)

From the controls of the Islamic media to reduce crime: controls the Islamic media in the future audience for the media message: 1 - follow the right and symptoms of evil and its people. 2 - Accept the knowledge and deal with it positively. 3 - not to be fooled by all that is presented. 4. Choose from media exposure 5. Do not exaggerate information received. 6. Avoid blind fanaticism. (hesham.2009), All aimed at reducing crime.

In conclusion, the criminal legislation represented by the penal system, as well as the readable Islamic media represented by the Holy Quran, the Sunnah, and the consensus of the scientist of Islam, audio and visual, represented by speeches and lessons that draw from what has been and published through what has been heard in the media and the web focuses on the need to reduce crime to save religion, soul, mind, supply and money.

\section{Previous studies:}

1) The study of Musa Halasa and Nasser Al-Mahdi (2010) This study aimed to identify the role of the media in formalization social awareness among the Palestinian youth. The importance of this study is to contribute to understanding the role of the media on social awareness among university students. The role of the media in crystallizing and formalization social awareness among university students.

2) The study of Emtieaz Saleh (2008) This study aimed to develop a proposed model for the role of the media in the process of socialization of high school students in Jordan, within a range of independent variables (gender, economic level of the family, the educational level of the father and mother, and the location of the school).the results found that the behavioral field ranked first, then the cognitive field in the second rank and finally the emotional field in the third rank the results showed that there were statistically significant differences due to gender in the three magazines mentioned above. The differences were in favor of students with level (80-200). It was also found that there are differences of significant significance attributed to the educational level of the father there were differences in favor of the secondary education level. The independent variable, the educational level of the mother, was in favor of the illiterate educational level. For the last independent variable, the school site was the difference for the benefit of the village children.

3) The study of Tahsen Mansour (2006) This study aimed to identify the role of Jordanian TV in formalization the attitudes of university youth towards the issue of terrorism within the framework of the theory of relying on the media. The study reached results such as: Arab satellite channels and the Internet as the first reliable sources to obtain information about terrorism and statistical differences Between Gender and Dependence on Sources (Jordan Television, Jordan Radio, Family, University) the study found that there are statistically significant differences in follow-up of general issues and problems according to the gender variable, represented in the political reform and the Palestinian-Israeli conflict. There is also a relationship between sex and the awareness of young people of the extent of the impact of terrorist events in Jordan. There is no such relationship in the awareness of young people of the extent of the impact of terrorist events in international tourism. The latest results of the study 
showed that the emotional effects in the first ranking as one of the effects of exposure to information of the terrorist case Cognitive and behavioral effects.

4) The study of Al-Tojairi (2002) This study aimed to identifying the role of security media and its characteristics in establishing the comprehensive concept of security and communication in the Saudi society the results of this study were the creation of a security information center. through which the objectives related to security and planning of security and development issues and in accordance with the developments and challenges of the era, and the need to rely on scientific and objective methods in all data and information and facts and study trends in public opinion, and the latest results need to deepen the bonds of cooperation with the various media.

5) The study of Al-Ghamdi study (2000) This study aimed at identifying the positive functions of the security media and identifying how to present terrorism issues through the media in the Arab world. It also aimed to identify what impedes the functions of security media in the prevention of terrorism. (Middle East, Egyptian Al Ahram), the results of this study include the interest of security media at the level of the Arab press and Arab universities to highlight its important role in the fight against terrorism and the establishment of a unified Arab base for media information and security awareness. In Arab countries finally, the importance of training media cadres to deal with security events.

6) The study of Wolker (1990) This study aimed to revealing the relationship between knowledge and parental factors and the extent of their impact on adolescents' viewing of television violence, one of the findings of this study was that the most adolescents decided that their goal was to watch the most aggressive television violence, that the trends were stronger to predict aggression, that parental factors play a later mediating role to watch violence, and the latest findings that watching violence is less important than the tendency to violence .

7) The study of skofeled (1989) This study aimed to identify the impact of television films on the attitudes of adolescents towards nuclear war and the results of the study that the film has a real impact on the dimensions related to the environment and predict the dangers of nuclear war.

\section{Methodology of the study (method and procedures)}

\section{Validity of the study instrument:}

After the preparation and design of the questionnaire was presented to a number of faculty members at the University of Balqa Applied who hold a doctorate degree in social and educational sciences, where some modifications were made to the questionnaire, until the questionnaire was finalized in the approval of $94 \%$ of these arbitrators, This ratio supports the validity of the apparent content of this tool. After analyzing the resolution paragraphs, the values of Pearson coefficients were positive and ranged from 0.40 to 0.69 between the score of each resolution item and the total score on the questionnaire. This ratio is sufficient to indicate the internal consistency of the terms the tool .

\section{Stability of the study instrument:}

The researchers distributed an experimental questionnaire to the sample of the students of the university, which numbered 60 students, half of them male and the other female, The goal was to ensure the clarity and accuracy of the questionnaire questions as a measurement tool, these students were excluded from the final sample. the researchers carried out a pilot distribution of the questionnaire on a sample of 60 university students, half of them male and female. The goal was to ascertain the accuracy and accuracy of the questionnaire questions as a measurement tool, and these students were excluded from the final sample. The questionnaire was redistributed two weeks after the first distribution of the questionnaire. The sample was 180 students, it was found that the correlation coefficient between the sample instrument in the first application and its performance in the second application was 0.89 , which is an acceptable stability coefficient for the purposes of this study.

Study community: Jordanian university students who are studying for the academic year 2018/2019

Study Sample: The study sample consisted of (1800) male and female students who were randomly selected from the study community, as shown in the following table (1). 


\section{Table (1)}

Distribution of sample members according to personal variables $(\mathrm{n}=1800)$

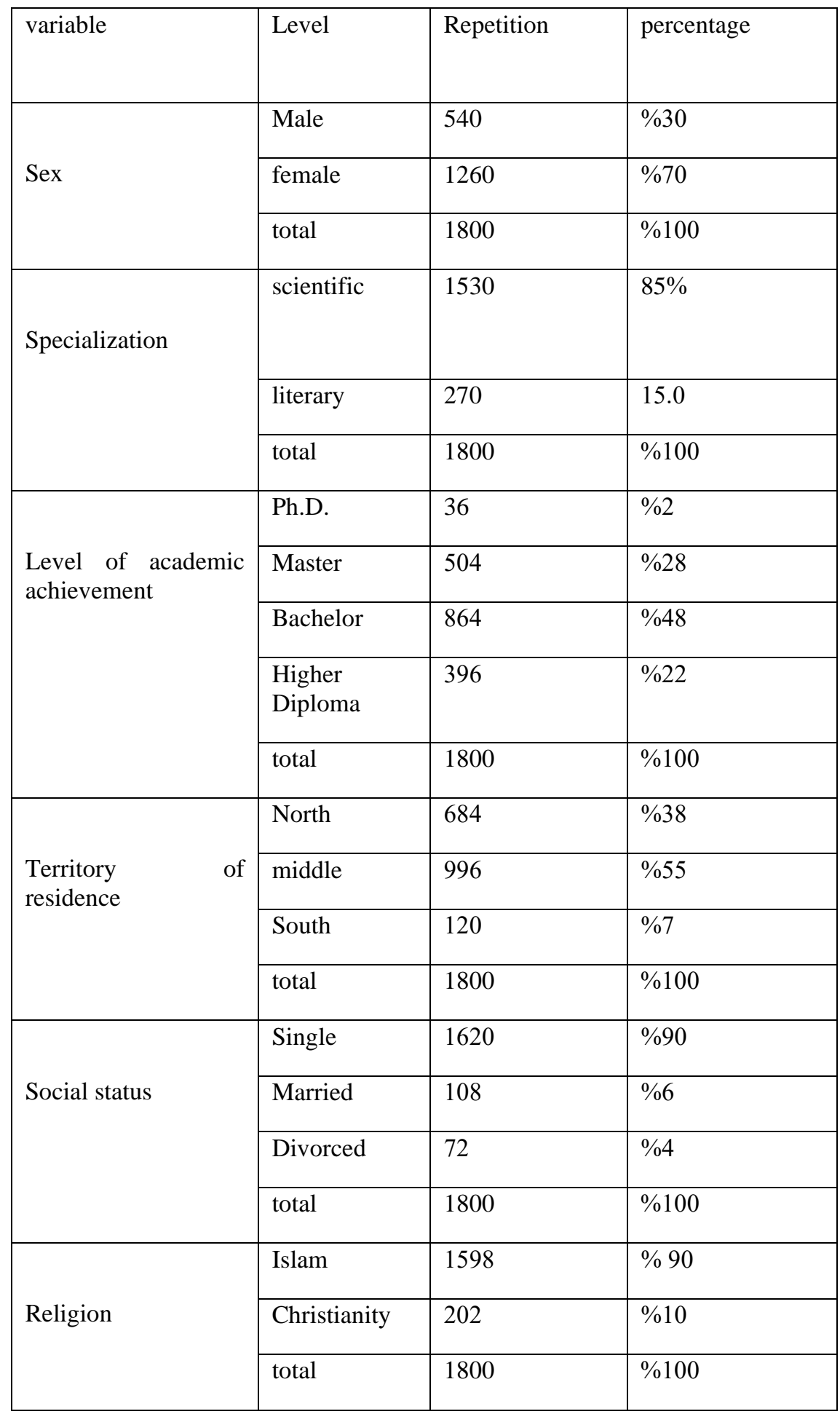

\section{The following table shows the following:}

1. The percentage of males in the sample (30\%), while the percentage of females $(70 \%)$.

2. The percentage of the distribution of the subjects of the specialization variable was (85\%) for scientific specialization, while the percentage of literary specialization was (15\%). 
3. The highest percentage of the distribution of the sample was according to the level of academic attainment (48\%) for the bachelor level, while the lowest percentage (2\%) for the level of (doctorate).

4. The highest percentage of the distribution of the sample was according to the variable of the region of residence $(55 \%)$ for the central region, while the lowest percentage $(7 \%)$ for the southern region.

5. The highest percentage of the sample of the study according to the social situation variable $(90 \%)$ of the social situation (single), while the lowest percentage (4\%) of the social situation (Divorced)

6. The majority of the sample of the Islamic religion is a percentage $(90 \%)$, while the percentage of followers of Christianity is (10\%).

\section{View results}

The results of the study "The role of the media tools in struggle crime" are presented below. The results of the study will be presented through verification by answering the study questions:

Question 1: Is there a role for the media tools in struggle crime from the point of view of the sample?

To answer this question and then to extract the arithmetical averages and standard deviations of respondents' responses from the "media role in the fight against crime" sections. One sample $T_{-}$test was applied to a field as a whole, Table 2.3 shows.

\section{Table (2)}

The arithmetical averages and the standard deviations of the sample responses for the field paragraphs the role of the media tools in struggle crime

\begin{tabular}{|c|c|c|c|}
\hline Number & Paragraph & SMA & Standard Deviation \\
\hline 1 & $\begin{array}{l}\text { There is a role for the media tools in } \\
\text { spreading the crime. }\end{array}$ & 1.65 & 0.46 \\
\hline 2 & $\begin{array}{l}\text { I think that the media tools contribute to } \\
\text { reducing the spread of crimes in society. }\end{array}$ & 1.65 & 0.46 \\
\hline 3 & $\begin{array}{l}\text { The Internet contributes to the reduction of } \\
\text { crime. }\end{array}$ & 1.41 & 0.49 \\
\hline 4 & $\begin{array}{l}\text { Television plays a major role in distribute } \\
\text { information about all forms of crime. }\end{array}$ & 1.69 & 0.43 \\
\hline 5 & $\begin{array}{l}\text { I think the role of television has become } \\
\text { weak in reducing the phenomenon of crime. }\end{array}$ & 1.77 & 0.47 \\
\hline 6 & $\begin{array}{l}\text { Radio is a media tools that contributes to } \\
\text { reducing the phenomenon of crime. }\end{array}$ & 1.43 & 0.50 \\
\hline 7 & $\begin{array}{l}\text { Newspapers and magazines contribute to } \\
\text { spreading awareness to struggle forms of } \\
\text { crime. }\end{array}$ & 1.80 & 0.43 \\
\hline 8 & $\begin{array}{l}\text { I think the media tools has contributed to the } \\
\text { spread of new forms of crime }\end{array}$ & 1.57 & 0.51 \\
\hline 9 & $\begin{array}{l}\text { The media do not seek to cover all the } \\
\text { features of the crimes. }\end{array}$ & 1.162 & 0.47 \\
\hline 10 & $\begin{array}{l}\text { I think that the media tools need to support } \\
\text { other institutions to reduce the phenomenon } \\
\text { of crime. }\end{array}$ & 1.83 & 0.41 \\
\hline 11 & $\begin{array}{l}\text { I think that the media tools is hesitant about } \\
\text { transfer media messages about some crimes. }\end{array}$ & 1.79 & 0.40 \\
\hline \multicolumn{2}{|r|}{ The role of media in struggle crime as a whole } & 1.169 & 0.14 \\
\hline
\end{tabular}

The above table shows that the statistical averages of the responses of the sample of the study sample on the role of the media in the fight against crime ranged from $\left(-1.41_{-} 1.83\right)$, the highest of which was paragraph (10) "I think the media tools need support from other institutions to reduce the phenomenon of crime "And the lowest 
of paragraph (6)" Radio as a media tool contributes to the reduction of the phenomenon of crime ", and the arithmetic average of a field as a whole (1.69).

\section{Table (3)}

Results of a test application.(T- test One Sample)

\begin{tabular}{|l|l|l|l|l|l|}
\hline Paragraph & SMA & standard deviation & $\mathrm{T}$ & $\begin{array}{l}\text { Degrees of } \\
\text { freedom }\end{array}$ & $\begin{array}{l}\text { Statistical } \\
\text { significance }\end{array}$ \\
\hline $\begin{array}{l}\text { The role of the media } \\
\text { tools in struggle crime } \\
\text { from the point of view } \\
\text { of individual members }\end{array}$ & 1.69 & 0.14 & 12.33 & 98.00 & 0.00 \\
\hline
\end{tabular}

From the previous table, the value of $\mathrm{T}$ (12.31) is positive and not statistically significant at the evidence level $(0.05=\alpha)$ and the standard mark for binary $(1.5)$, where the total arithmetic mean (1.69) a value higher than the standard mark, this shows that there is a role for the media in struggle crime from the point of view of the sample members.

\section{second question:}

To what extent do local media tools Contribute agree to reduce crime?

To answer this question, the arithmetical averages and the standard deviations of the responses of the sample were extracted from the paragraphs of "The extent of the contribution of the local media to crime reduction", and the "One Sample T_test"

On an area as a whole, table (4-5) illustrate this.

\section{Table (4)}

The statistical averages and the standard deviations of respondents' responses to the paragraphs of the field of the contribution of the local media to the reducing of crime

\begin{tabular}{|r|l|r|r|}
\hline Number & Paragraph & SMA & \multicolumn{1}{|c|}{ Standard Deviation } \\
\hline 1 & theft & 2.88 & 1.09 \\
\hline 2 & cheating & 2.56 & 0.82 \\
\hline 3 & the kill & 2.50 & 0.96 \\
\hline 4 & Addiction & 2.50 & 1.11 \\
\hline 5 & Sexual relations & 2.28 & 1.04 \\
\hline 6 & Extremism & 2.34 & 0.88 \\
\hline 7 & Violence & 2.60 & 0.98 \\
\hline 8 & Corruption & 2.68 & 0.97 \\
\hline 9 & Moral Dissolution & 2.50 & 1.20 \\
\hline \multicolumn{2}{|l|}{$\begin{array}{l}\text { The field of the contribution of local media in reducing } \\
\text { crime as a whole }\end{array}$} & 2.53 & 0,65 \\
\hline
\end{tabular}

The above table shows that the statistical averages of the responses of the sample members on the extent of the contribution of the local media to the reducing of the crime ranged between (2.28-2.88), the highest of which was paragraph (1) "theft", and the lowest of paragraph (5) "sexual relations" The arithmetic mean for a field as a whole was 2.53 . 
Table (5) Results of the application of the choice of (T-test One Sample) on the extent of the contribution of the local media in reducing the crime from the point of view of the sample members.

\begin{tabular}{|l|r|r|r|r|r|}
\hline Paragraph & SMA & standard deviation & T & $\begin{array}{r}\text { Degrees of } \\
\text { freedom }\end{array}$ & $\begin{array}{r}\text { Statistical } \\
\text { significance }\end{array}$ \\
\hline $\begin{array}{l}\text { The field of the } \\
\text { contribution of local } \\
\text { media tools in reducing } \\
\text { crime }\end{array}$ & 2.53 & 0.65 & -0.44 & 98 & 0.73 \\
\hline
\end{tabular}

The previous table shows that the value of $\mathrm{T}(-0.44)$ is a negative value and is not statistically significant at the evidence level $(0.05=\alpha)$ and the mark for the quadratic standard (2)where the total arithmetic mean (2.53)a value higher than the standard mark, this indicates a degree of local media contribution to crime reducing.

\section{Summary of results:}

After reading the statistical analysis of individual sample responses

1. There is a prominent role for the media in reducing crime.

\section{Recommendations}

1. Activate the role of the mass media in raising awareness to reduce crimes.

2. Conduct further studies and research on the media and crime.

\section{References}

1- Holy Quran, Surat Al-Noor: Verse 2.

2- Holy Quran, surat Al-Baqra:179.

3- Al Abdullah, May,(2010),"The Role of Arab Space Media in the Arab Revolutions", Arab League for Communication Sciences, Lebanese University.

4- Al-Bukhari, Abu Abdullah Muhammad ibn Isma'il ibn Ibrahim al-Jaafi, (256 Hijri), Book of the alhudud, Volume 8, page 166, no .: 6820 .

5- Al-Bukhari, Abu Abdullah Muhammad ibn Isma'il ibn Ibrahim al-Ja`afi, (256 Hijri), Book of the alhudud, Volume 8, page 159, no .: 6785 .

6- Al-Bukhari, Abu Abdullah Muhammad ibn Isma'il ibn Ibrahim al-Ja`afi, (256 Hijri), Book of the alhudud, Volume 8, page 159, no .: 6784.

7- Al-Harish, Faraj Saleh,(1999), "Criminology", (Edition1), National Library - Benghazi, Libya.

8- Al-Janahi, Ali bin Fayez,(2000). "Security Media and Crime Prevention", Naif Arab Academy for Security Sciences, Center for Studies and Research, Riyadh, Saudi Arabia.

9- Al-Janahi, Ali bin Fayez,(1990). "A Look at the Security Media", Journal of Security, Ministry of the Interior of Saudi Arabia, Volume (I), No. (8).

10- Al-Ghamdi, Yousef bin Ahmed,(2000). "Positive Functions of Security Media in the Prevention of Terrorism", unpublished Master Thesis, Naif Arab University for Security Science, Riyadh, Saudi.

11- Al-Maroudi, Abu al-Husayn Ali bin Muhammad bin Habib al-Basri,(2002), The Rulings of the Sultan, Dar al-Fikr, Beirut, Lebanon.

12- Al-Tojairi, Walid bin Saad,(2002). "Unpublished Master Thesis, Naif Arab University for Security Sciences, Saudi.

13- Al-Qurtubi, Muhammad ibn Ahmad,(1964), exegesis al-Qurtubi, Egyptian Book Publishing House, part12, edition 2, Cairo, Egypt.

14- Done Nimmo \&Michael Mansfeild,(1982), Government and the News Media : Comparative Dimentions . Waco Texas : Paylor University Press.

15- Halsa, Moussa, Nasser Mahdi,(2010), "The role of the media in shaping social awareness among youth", Al-Azhar University Journal, Human Sciences Series 2010, No. (2), Gaza, Palestine.

16- Hesham, Alaa Ahmed,(2009), media components controls methods in the light of the Holy Quran ,Master dissertation, Islamic University, College of Interpretation Department of Quran Sciences, Gaza, Palestine.

17- Ibid,pp123-124 


\section{8- Ibid,pp113-117}

19- Ghanim, Abdulla Abd Alghani,(1994),"Islamic Criminal Sociology", First Book, "Criminal Crime from an Islamic Perspective to General Islamic Theory of Crime, Modern University Office, Alexandria, Egypt.

20- Mansour, Tahseen,(2006). "The role of Jordanian television in shaping the attitudes of university youth towards the issue of terrorism", Journal of Humanities and Social Studies, No. (3), (2008), Yarmouk University, Jordan.

21- Mathkoor, Ibrahim et al,(1985),Dictionary of Social Sciences, (Edition 1), Egyptian Book Authority, Cairo, Egypt.

22- Saleh, Emtieaz,(2008),"Developing a Proposed Model for the role and the media in the process of socialization of high school students in Jordan", PhD thesis, College of Graduate Studies. University of Jordan, Jordan.

23- Shoman, Mohammed Ali, (1420 Hejri), "Media and Juvenile Delinquency", Crime Research Center, Riyadh - Saudi Arabia.

24- Skofeled, Sane - W , Pavelchak - Mark . A , (1989), The Impact Of A TV Film On Attitudes Relsed To Nuceuler War, US .A : Sourball Of Applied - Social Psychology, Vol 19(50) P.P a33- 448.

25- Talb, Hassan, (2002), "Sociology of Crime, Punishment and Correctional Institutions", Dar Al Tali'ah, Beirut, Lebanon.

26- Turki, Mustafa,(1984),Media and its impact on the personality of the individual, Journal of the World of Thought, Volume: 14, Number: 4, 1, Ministry of Information Kuwait, Kuwait.

27- Wolker , Kim _bmoly_douald D , (1990), Attitudes And Pareutal Factors As Intervening In The Television Violence . 